\title{
Nienna chukotka sp. nov. (Protura, Acerentomidae, Nipponentominae) from the Arctic region, with a key to species of the genus
}

\author{
Julia Shrubovych ${ }^{1,2,3}$ \\ I Institute of Soil Biology, Biology Centre, Czech Academy of Sciences, Na Sádkách 7, 37005 České Budějovice, \\ Czech Republic 2 Institute of Systematics and Evolution of Animals, Polish Academy of Science, Stawkowska \\ 17, Pl31-016 Krakow, Poland 3 State Museum of Natural History, Ukrainian Academy of Sciences, Teatral'na \\ St. 18, UA 79008 Lviv, Ukraine \\ Corresponding author: Julia Shrubovych (shrubovych@gmail.com)
}

Academic editor: W. M. Weiner | Received 3October 2019 | Accepted 26 November 2019 | Published 12 December 2019

http://zoobank.org/OEDFAA7D-133C-462D-BDB3-B38A228FFE57

Citation: Shrubovych J (2019) Nienna chukotka sp. nov. (Protura, Acerentomidae, Nipponentominae) from the Arctic region, with a key to species of the genus. ZooKeys 899: 37-45. https://doi.org/10.3897/zookeys.899.47030

\begin{abstract}
A new species of Nienna was collected in the most northern part of the Palearctic, inside the Arctic Circle. In possessing seta $P c$ on tergite VII and sternites VI-VII and a very long foretarsal sensillum a, Nienna chukotka sp. nov. is more similar to Alaskaentomon species than to the other Nienna species distributed in southern Siberia and northern China. The new species differs from nearly all other members of Nipponentominae in possessing five anterior setae on tergite VII and in the presence of posterolateral pores on tergite I, as in members of Hesperentomon (Hesperentomidae). An identification key to Nienna species is provided.
\end{abstract}

\section{Keywords}

Chaetotaxy, Chukotka, identification key, northern Palearctic, porotaxy

\section{Introduction}

The proturan genus Nienna Szeptycki, 1988 was created for Nienna parvula Szeptycki, 1988, described from the Altai mountains in southern Siberia (Szeptycki 1988). The genus differs from the 12 other genera of Nipponentominae Yin, 1983 in possessing a small, indistinctly granulated calyx and a short posterior filament on the maxillary

Copyright Julia Shrubovych. This is an open access article distributed under the terms of the Creative Commons Attribution License (CC BY 4.0), which permits unrestricted use, distribution, and reproduction in any medium, provided the original author and source are credited. 
gland, and in the small, nearly globular foretarsal sensillum t3. A second species, Nienna quinghaiensis $\mathrm{Bu} \&$ Yin, 2008, was described from northern China. The diagnosis of the genus was recently updated (Galli et al. 2018). In the current paper, the description of a third species of Nienna is given. The type specimens, collected from the Arctic region, are the northernmost records for any Protura. A key to the species of Nienna is given.

\section{Materials and methods}

Protura specimens collected from western Chukotka in 2018 were extracted from soil samples with Berlese-Tullgren funnels into 95\% ethanol. The specimens were mounted on glass slides in Faure's medium (Dunger and Fiedler 1989).

The classification system of Protura follows Szeptycki (2007). Terminology for body chaetotaxy and porotaxy follows Szeptycki (1988) and Shrubovych (2014); head seta designations follows Rusek et al. (2012).

\section{Abbreviations}

$\begin{array}{llll}\text { Abd. } & \text { abdominal segments, } & \boldsymbol{s a l} & \text { sternal anterolateral, } \\ \text { Th. } & \text { thoracic segments, } & \boldsymbol{p s m} & \text { posterosubmedial, } \\ \boldsymbol{A} \text {-setae } & \text { anterior setae, } & \boldsymbol{p s} \boldsymbol{\text { posterosublateral, }} \\ \boldsymbol{P} \text {-setae } & \text { posterior setae, } & \boldsymbol{p l} & \text { posterolateral, } \\ \boldsymbol{f} \boldsymbol{p} & \text { frontal, } & \boldsymbol{s p m} & \text { sternal posteromedial, } \\ \boldsymbol{c} \boldsymbol{p} & \text { clypeal, } & \boldsymbol{s p s m} & \text { sternal posterosubmedial cu- } \\ \boldsymbol{a l} & \text { anterolateral, } & & \text { ticular pore. } \\ \boldsymbol{s} \boldsymbol{l} & \text { sublateral, } & & \end{array}$

\section{Results}

The genus Nienna is characterized by three pairs of $A$-setae on the mesonotum and metanotum, small, indistinctly granulated appendices on the calyx and a short posterior filament on the maxillary gland. The foretarsal sensillum $t 1$ is filiform, sensillum t3 is small and globular (lanceolate in N. quinghaiensis Bu \&Yin, 2008), the position of sensillum $d$ is close to the base of $e$, and seta $\beta 1$ is setiform. Sensillum $a^{\prime}$ is distal to the base of $t 2$. Sensillum $b$ 'is missing. The genus is similar to twelve other genera from the subfamily Nipponentominae in having abdominal legs with 2 nearly equal setae, 5 pairs of $A$-setae on tergites II-VI (except for Alaskaentomon Nosek, 1977 and Nanshanentulus $\mathrm{Bu} \&$ Yin, 2007) and by the posterior position of seta $P 3$ on abdominal tergites II-VI (except for A. ffellbergi Nosek, 1977) (Bu and Yin 2007; Bu et. al. 2013; Galli et al. 2018; Nosek 1977, 1981; Shrubovych 2009, 2011, 2014; Shrubovych and Smykla 2012; Shrubovych et al. 2012; Shrubovych et al. 2014a, b, c). 
Nienna chukotka sp. nov.

http://zoobank.org/2FEE913F-CC4C-445A-869E-F25B7267F644

Figs 1, 2, Table 1

Material examined. Holotype (ISEA 6650): female, Russia, Chukotka Autonomous Okrug, Chaunskiy district, 2 kilometers from Apapelgino village, hill Akanotenmeem, in dry locality with Dryas sp., elev. $20 \mathrm{~m}, 69^{\circ} 48^{\prime} 40^{\prime \prime} \mathrm{N}, 170^{\circ} 35^{\prime} 51^{\prime \prime E}, 24-\mathrm{VII}-2018$, coll. Makarov K. and Makarova O. Paratype (ISEA 6651): female, same data as holotype. The holotype and paratype are deposited in the collection of the Institute of Systematics and Evolution of Animals, Krakow, Poland (ISEA).

Diagnosis. Nienna chukotka is characterized by 3 pairs of $A$-setae on the mesonotum, metanotum and tergite VIII, $3 A$-setae on sternites I-VII, absence of P1a setae on tergites I-VI, 5 pairs of $A$-setae on tergites II-VII, absence of $A 2$ on prosternum, presence of seta $P c$ on tergite VII and sternites VI-VII, and presence of additional $d 6$ setae on head. Foretarsal sensillum $a$ is broadened, very long, surpassing the base of sensillum $e$. Posterolateral pores $(p l)$ present on tergite I, $p s l$ pores present on tergites VI and VII, asymmetrical spsm pores present on sternites IV-VII.

Description. Head setae $13, s d 4$ and $s d 5$ long, setiform, additional seta $d 6$ present, length ratio of posterior setae $d 7: s d 7: 15$ as 2.4:2.5:1.0; frontal pore $(f p)$ and a pair of clypeal $(c p)$ pores present (Fig. 1A). Pseudoculus circular, with short posterior extension, $\mathrm{PR}=12$ (Fig. 1B). Sensilla of maxillary palps slender, pointed apically, equal in length (Fig. 1C). Labial palps with four-branched tuft of apical setae and broadened sensillum (Fig. 1D). Maxillary gland with small, indistinctly granulated calyx, short posterior filament and trilobed posterior dilation (Fig. 1E), CF =6.0.

Foretarsus (Fig. 1J, H) without sensillum $b$; $t 1$ filiform, $t 3$ small and globular; $a$ broad, very long, evidently surpassing base of seta $\gamma 3$, nearly reaching base of sensillum $f$; other sensilla parallel-sided. Sensillum $b$ slightly longer than $c$. Sensillum $d$ situated nearer to $e$ than to $c$; $a$ distal to level of $t 2$ insertion. Length formula of sensilla: $t 3<t 1$ $<t 2<(c=e)<b<\left(g=a^{\prime}=c\right)<(d=f)<a$. Setae $\beta 1$ and $\delta 4$ long and setiform, about twice as long as other $\delta$-setae (Fig. $1 \mathrm{H})$. Single pores situated near bases of sensilla $t 1$ (Fig. 1J) and $t 3$ (pore not visible on Fig. 1J because closed by sensillum e). Claw short, without inner tooth, empodial appendage short. $\mathrm{BS}=0.4, \mathrm{TR}=2.7, \mathrm{EU}=0.3$.

Formula of chaetotaxy given in Table 1. Setae on nota differing in length (Fig. 2A, B). Pronotal seta 11.6 times longer than seta 2 (Fig. 1A). Meso- and metanota with setae $P 1 a$ and $P 2 a$ setiform, lengths 7 and $5 \mu \mathrm{m}$, respectively; $P 2 a$ situated nearly midway between P2 and P3 (Fig. 2A, B). Length ratio of mesonotal setae P1: P1a: $P 2$ as 2.7: 1: 3.6. Meso- and metanota with $s l$ and $a l$ pores (Fig. 2B). Pro-, meso- and metasterna without pores (Fig. 2E, F).

Accessory setae on tergites and sternites I-VII setiform, those of tergite VII significantly longer than those on I-VI. (Fig. 2C, D, G, H, K, L). Pores plpresent on tergite I, psm on tergites I-VII, psl on tergites VI-VII, al on tergites II-VII (Fig. 2C, D, H).

Abdominal legs with 4, 2, 2 setae. Subapical and lateral apical setae on second and third pairs of abdominal legs nearly equal in length, 15 and $14 \mu \mathrm{m}$, respectively 

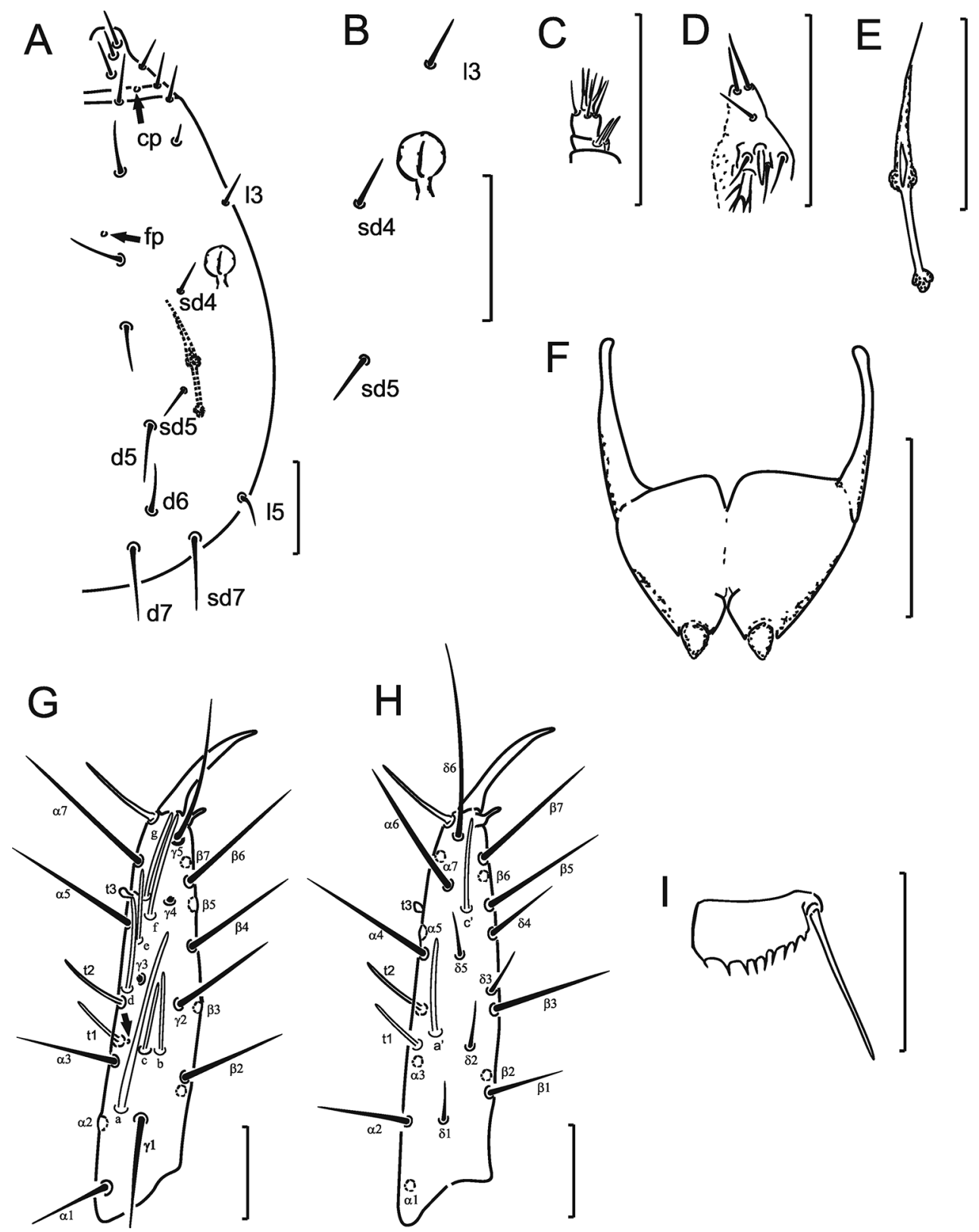

Figure I. Nienna chukotka sp. nov. holotype. A Part of head B pseudoculus with setae $s d 4$, $s d 5$ and $l 3$ $\mathbf{C}$ maxillary palpus $\mathbf{D}$ labial palpus $\mathbf{E}$ maxillary gland $\mathbf{F}$ female squama genitalis $\mathbf{G}$ exterior view of foretarsus $\mathbf{H}$ interior view of foretarsus $\mathbf{I}$ comb. Arrows show pores. Scale bars: $20 \mu \mathrm{m}$.

(Fig. 2J). Sternites I-III without pores (Fig. 2G). Sternites IV-VII with asymmetrical spsm pore, with short anterolateral lines and sternite VII with a connecting line on anterior part (Figs 2K, L). 


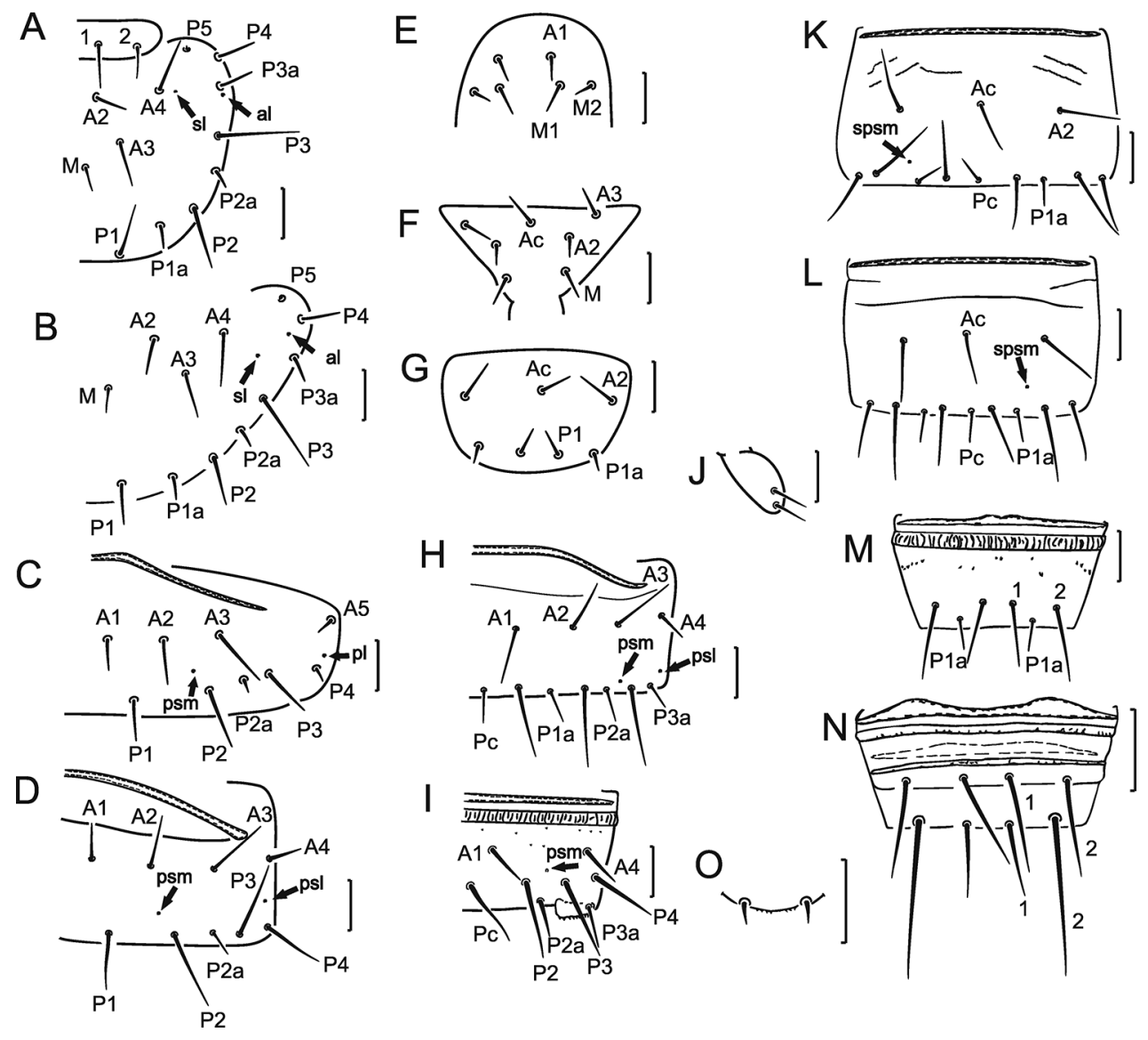

Figure 2. Nienna chukotka sp. nov. holotype. A Part of pro- and mesonotum B part of metanotum $\mathbf{C}$ part of tergite I D part of tergite VI $\mathbf{E}$ anterior part of prosternum $\mathbf{F}$ anterior part of mesosternum $\mathbf{G}$ sternite I $\mathbf{H}$ part of tergite VII I part of tergite VIII J abdominal leg of segment II $\mathbf{K}$ sternite VI $\mathbf{L}$ sternite VII $\mathbf{M}$ sternite VIII $\mathbf{N}$ sternites IX-X $\mathbf{O}$ hind margin of sternite XII. Arrows show pores. Scale bars: $20 \mu \mathrm{m}$.

Abdominal segment VIII with distinct striate band; tergite and sternite anteriorly with irregular small teeth (Figs 2 I, M). Pore psm without accompanying teeth. Posterior margin of sternite VIII and laterotergites smooth. Comb VIII with 9-10 small teeth (Fig. 1I). Seta $1 a$ on tergite IX half the length of seta 1 . Seta $2 a$ on tergites IX and $\mathrm{X}$ shorter than other setae. Sternites IX-X with traces of striate band (Fig. 2N). Setae 1 and 2 on sternite IX of equal length, on sternite $\mathrm{X}$ seta 1 about half the length of seta 2 (Fig. $2 \mathrm{~N}$ ). Medial pore on dorsal lobe of segment XII and pair of sal pores on ventral lobe. Hind margin of dorsal lobe smooth, ventral lobe with fine serrations (Fig. 2O).

Female squama genitalis with short, pointed acrostyli (Fig. 1F).

Body measurements ( 2 females) (in $\mu \mathrm{m}$ ): maximum body length 1004, head 115, pseudoculus 8 , lever 3 , posterior part of maxillary gland 12 ; pronotal setae 118,211 ; mesonotal setae P1 19, P1a 7, P2 25, M10, foretarsus 94-95, claw 30, empodial appendage 4 . 
Table I. Body chaetotaxy of Nienna chukotka sp. nov.

\begin{tabular}{|c|c|c|c|c|}
\hline & \multicolumn{2}{|c|}{ Dorsal } & \multicolumn{2}{|c|}{ Ventral } \\
\hline Segment & Formula & Setal composition & Formula & Setal composition \\
\hline Th. I & 4 & 1,2 & $(2+4) / 6$ & $\begin{array}{l}\text { A1, M1, 2, } \\
\text { P1, 2, } 3\end{array}$ \\
\hline Th. II & $8 / 16$ & $\begin{array}{c}\mathrm{A} 2,3,4, \mathrm{M} \\
\mathrm{P} 1,1 \mathrm{a}, 2,2 \mathrm{a}, 3,3 \mathrm{a}, 4,5\end{array}$ & $(5+2) / 4$ & $\begin{array}{c}\text { Ac, } 2,3, \mathrm{M} \\
\mathrm{P} 1,3\end{array}$ \\
\hline Th. III & $8 / 16$ & $\begin{array}{c}\mathrm{A} 2,3,4, \mathrm{M} \\
\mathrm{P} 1,1 \mathrm{a}, 2,2 \mathrm{a}, 3,3 \mathrm{a}, 4,5\end{array}$ & $(7+2) / 4$ & $\begin{array}{c}\text { Ac, } 2,3,4, M \\
\quad P 1,3\end{array}$ \\
\hline Abd. I & $8(6) / 10$ & $\begin{array}{c}\mathrm{A} 1,2,(3), 5 \\
\mathrm{P} 1,2,2 \mathrm{a}, 3,4\end{array}$ & $3 / 4$ & $\begin{array}{l}\text { Ac, } 2 \\
\text { P1, 1a }\end{array}$ \\
\hline Abd. II-III & $10 / 14$ & $\begin{array}{c}\mathrm{A} 1,2,3,4,5 \\
\mathrm{P} 1,2,2 \mathrm{a}, 3,4,4 \mathrm{a}, 5\end{array}$ & $3 / 5$ & $\begin{array}{c}\text { Ac, } 2 \\
\text { Pc, } 1 \mathrm{a}, 2\end{array}$ \\
\hline Abd. IV-V & $10 / 14$ & $\begin{array}{c}\mathrm{A} 1,2,3,4,5 \\
\mathrm{P} 1,2,2 \mathrm{a}, 3,4,4 \mathrm{a}, 5\end{array}$ & $3 / 8$ & $\begin{array}{c}\mathrm{Ac}, 2 \\
\mathrm{P} 1,1 \mathrm{a}, 2,3\end{array}$ \\
\hline Abd. VI & $10 / 14$ & $\begin{array}{c}\mathrm{A} 1,2,3,4,5 \\
\mathrm{P} 1,2,2 \mathrm{a}, 3,4,4 \mathrm{a}, 5\end{array}$ & $3 / 9$ & $\begin{array}{c}\text { Ac, } 2 \\
\text { Pc, } 1,1 \mathrm{a}, 2,3\end{array}$ \\
\hline Abd. VII & $10 / 19$ & $\begin{array}{c}\mathrm{A} 1,2,3,4,5 \\
\mathrm{Pc}, 1,1 \mathrm{a}, 2,2 \mathrm{a}, 3,3 \mathrm{a} \\
4,4 \mathrm{a}, 5\end{array}$ & $3 / 9$ & $\begin{array}{c}\text { Ac, } 2 \\
\text { Pc, } 1,1 \mathrm{a}, 2,3\end{array}$ \\
\hline Abd. VIII & $6 / 15$ & $\begin{array}{c}\mathrm{A} 1,4,5 \\
\text { Pc, } 2,2 \mathrm{a}, 3,3 \mathrm{a}, 4,4 \mathrm{a}, 5\end{array}$ & $4 / 2$ & $\begin{array}{l}1,2 \\
\text { P1a }\end{array}$ \\
\hline Abd. IX & 12 & $1,1 \mathrm{a}, 2,2 \mathrm{a}, 3,4$ & 4 & 1,2 \\
\hline Abd. X & 10 & $1,2,2 \mathrm{a}, 3,4$ & 4 & 1,2 \\
\hline Abd. XI & 6 & $1,3,4$ & 6 & \\
\hline Abd. XII & 9 & & 6 & \\
\hline
\end{tabular}

(3) - setae $A 3$ absent in paratype. Tergite I with $6 A$-setae.

Chaetal variability. In the holotype, seta $P 4$ is doubled asymmetrically on the mesonotum; in the paratype, seta $A 3$ is absent symmetrically on tergite I and seta $P 2 a$ is doubled on tergite VII.

Etymology. The species name is taken from the general locality where the specimens were collected.

Remarks. Nienna chukotka sp. nov. differs from $N$. parvula and N. quinghaiensis in the presence of seta $P c$ on tergite VII and sternites VI-VII (in $N$. quinghaiensis seta $P c$ is present on sternite VII only), the presence of 5 pairs of $A$-setae ( 4 pairs in the other two species) and $P 3 a$ on tergite VII, the shape of the accessory setae on tergites and sternites I-VI (setiform in the new species, sensilliform in the other two species) and the shape of foretarsal sensilla $a, c$ and $e$ (in the other species sensillum $a$ is shorter, reaching base of sensillum $t 2$, sensilla $c$ and $e$ short and broad). The porotaxy of mesoand metanota and abdominal sternites also differs: Nienna chukotka has two pairs of $s l$ and al pores on the meso- and metanota, and asymmetrical spsm pores on sternites IV-VII;], whereas $N$. parvula has a pair of $s l$ pores on the meso- and metanota, and a simple spm pore on sternites VI-VII. Nienna quinghaiensis has $a l$ and $l$ pores on the mesonotum, $l$ pores on the metanotum, and an spm pore on sternite VII. The new species is more similar to $N$. parvula in possessing traces of a striate band on sternites IX-X and in the globular foretarsal sensillum t3. Nienna chukotka is characterized by the presence of $p l$ on tergite I, which is the first report of posterolateral pores in Acerentomidae. Szeptycki (1988) previously described $p l$ pores on Hesperentomon martynovae 
Szeptycki, 1988 (Hesperentomidae) collected in the Altai Mts. These $p l$ pores have also been recorded in other Hesperentomon species: H. fopingense $\mathrm{Bu}$, Shrubovych \& Yin, 2011, H. nanshanensis Bu \& Yin, 2007, H. xiningense Bu \& Yin, 2007 distributed in China, and H. tianshanicum Martynova, 1970 (Shrubovych 2010).

\section{Discussion}

The foretarsus of $N$. chukotka sp. nov. has a very long sensillum $a$, surpassing the base of sensillum $e$, and filiform foretarsal sensillum $t 1$, characters shared with two species of Alaskaentomon (A. fjellbergi, A. condei). These two Alaskaentomon species possess seta Pc on tergite VII and sternites VI-VII. Alaskaentomon spp. differ from N. chukotka sp. nov. in having two pairs of $A$-setae on the meso- and metanota and large granulated appendices on the calyx of the maxillary gland (Shrubovych et al. 2014c). In notal chaetotaxy (three pairs of $A$-setae) and the filiform sensillum $t 1$, the genus Nienna is similar to the genera Callientomon Yin, 1980, Noldo Szeptycki, 1988, Paracerella Imadaté, 1980 and Verrucoentomon Rusek, 1974. However, Nienna differs from all of them in possessing small, indistinctly granulated appendices on the calyx of the maxillary gland and in the small, nearly globular foretarsal sensillum $t 3$ (Shrubovych et al. 2014a). The new species differs from nearly all species of Nipponentominae in possessing a pair of $A 1$ setae on tergite VII (five pairs of $A$-setae), while nearly all other nipponentomines have four pairs of $A$-setae (except Nipponentomon macleani Nosek, 1977 from Alaska, which also has 5 pairs of $A$ setae). Therefore, $N$. chukotka sp. nov. from Chukotka is more similar in body chaetotaxy and in foretarsal sensilla pattern to members of other genera distributed in Alaska than to the other Nienna species distributed in more southern regions of the Palearctic. This peculiarity could be an effect of subsequent allopatric speciation resulting from successive closings of the Bering Strait and cooling of the Arctic Ocean during the Pliocene-Pleistocene. Another interesting fact is that species recorded on the northern edge of proturan distribution (only a few Protura species are known from the Arctic region) possess a larger number of setae on the body than species with a more southern distribution.

\section{Key to Nienna species}

$1 \quad$ Foretarsal sensillum $a$ very long, surpassing base of sensillum $e$, tergite VII with 5 pairs of $A$-setae and with $P c, P 3 a$ present, sternites VI-VII with $P c$....

Nienna chukotka sp. nov.

- $\quad$ Foretarsal sensillum a short, nearly reaching base of sensillum $t 2$, tergite VII with 4 pairs of $A$-setae and without $P c, P 3 a$ absent, sternite VI without $P c$,

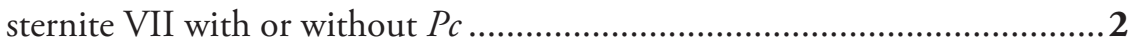

2 Foretarsal sensilla $b$ and $c$ nearly equal in length, seta $\delta 4$ setiform, sternite VII without $P c$

- $\quad$ Foretarsal sensillum $c$ half the length of $b$, seta $\delta 4$ sensilliform, sternite VII with $P c$ 


\section{Acknowledgements}

The author is very grateful to Kirill Makarov (Moscow State Pedagogical University) and Olga Makarova (Severtsov Institute of Ecology and Evolution) for Protura material from the western Chukotka, to Anatoly Babenko (Severtsov Institute of Ecology and Evolution) for valuable comments, to Ernest C. Bernard (University of Tennessee) for English corrections and remarks, to Osami Nakamura for the review and to the editor Wanda M. Weiner for her constructive comments.

\section{References}

Bu Y, Yin WY (2007) Two new species of Hesperentomon Price, 1960 from Qinghai Province, Northwestern China (Protura: Hesperentomidae). Acta Zootaxonomica Sinica 32(3): $508-514$.

Bu Y, Yin WY (2008) Occurrence of Nosekiella Rusek 1974 and Nienna Szeptycki 1988 (Protura: Nipponentomidae: Verrucoentominae) in China. Annales de la Société Entomologique de France 44(2): 201-207. https://doi.org/10.1080/00379271.2008.10697556

Bu Y, Shrubovych J, Yin WY (2011) Two new species of genus Hesperentomon Price, 1960 (Protura, Hesperentomidae) from Northern China. Zootaxa 2885: 55-64. https://doi. org/10.11646/zootaxa.2885.1.6

Bu Y, Wu D, Shrubovych J, Yin WY (2013) New Nipponentomon species from northern Asia (Protura: Acerentomata, Nipponentomidae). Zootaxa 3636(4): 525-546. https://doi. org/10.11646/zootaxa.3636.4.2

Dunger W, Fiedler HJ (1989) Methoden der Bodenbiologie. Gustav Fischer, Jena, 432 pp.

Galli L, Shrubovych J, Bu Y, Zinni M (2018) Genera of the Protura of the World: diagnosis, distribution, and key. ZooKeys 772: 1-45. https://doi.org/10.3897/zookeys.772.24410

Imadaté G (1980) A new genus of Acerentomidae (Protura) from Japan and North America. Kontyû 48: 278-290.

Martynova EF (1970) New species of Protura from the High Mountain Region of Tian Shan. Zoologicheskii Zhurnal 49: 236-240. [in Russian]

Nosek J (1977) A new genus and six new species of Protura from Alaska (Protura: Acerentomidae, Eosentomidae). Entomologica Scandinavica 8(4): 271-284. https://doi. org/10.1163/187631277X00378

Nosek J (1981) Three new Protura from Alaska with key to known Alaskan species (Insecta: Protura). Entomologica Scandinavica 12(2): 158-162. https://doi. org/10.1163/187631281794709827

Rusek J (1974) Zur Taxonomie einiger Gattungen der Familie Acerentomidae (Insecta, Protura). Acta entomologica bohemoslovaca 71: 260-281.

Rusek J, Shrubovych J, Szeptycki A (2012) Head porotaxy and chaetotaxy of order Acerentomata (Protura). Zootaxa 3262: 54-61. https://doi.org/10.11646/zootaxa.3262.1.5

Shrubovych J (2009) Nipponentomon jaceki sp. nov. from the Russian Far East (Protura: Acerentomidae, Nipponentominae). Zootaxa 2231: 55-61. https://doi.org/10.11646/zootaxa.2231.1.4 
Shrubovych J (2010) Redescription of Hesperentomon tianshanicum Martynova, 1970 (Protura: Acerentomata, Hesperentomidae) and key to Hesperentomon species. Zootaxa 2720: 28 34. https://doi.org/10.11646/zootaxa.2720.1.2

Shrubovych J (2011) Redescription of Verrucoentomon montanum new status (= Acerella montana Martynova) (Protura: Acerentomidae, Nipponentominae). Zootaxa 2743: 63-67. https://doi.org/10.1603/AN12135

Shrubovych J (2014) Identification and character analysis of the Acerentomidae (Protura) of the northeastern Palearctic (Protura: Acerentomidae). Zootaxa 3755(2): 136-164. https:// doi.org/10.11646/zootaxa.3755.2.2

Shrubovych J, Bernard EC (2012) Two new species of Verrucoentomon Rusek (Protura: Acerentomidae, Nipponentominae) and a key to species. Annals of the Entomological Society of America 105(5): 628-637. https://doi.org/10.1603/AN11175

Shrubovych J, Smykla J (2012) Review of the genus Paracerella Imadaté (Protura: Acerentomidae, Nipponentominae) with identification key and description of a new species. Zootaxa 3509: 69-76. https://doi.org/10.11646/zootaxa.3509.1.4

Shrubovych J, Rusek J, Bernard EC (2012) Redefinition and four new species of Yavanna Szeptycki and comparison with Nosekiella Rusek (Protura: Acerentomidae: Nipponentominae). Annals of the Entomological Society of America 105(1): 3-19. https://doi.org/10.1603/AN11119

Shrubovych J, Rusek J, Bernard EC (2014a) Revision of Vesiculentomon, Nosekientomon n. g. (Protura: Acerentomidae, Nipponentominae) with a key to genera of Nipponentominae. Annals of the Entomological Society of America 107(1): 74-80. https://doi.org/10.1603/ AN12135

Shrubovych J, Rusek J, Bernard EC (2014b) Revision of Nosekiella (Protura: Acerentomidae, Nipponentominae). Annals of the Entomological Society of America 107(4): 721-727. https://doi.org/10.1603/AN13160

Shrubovych J, Rusek J, Smykla J, Bernard EC (2014c) Revision of Alaskaentomon Rusek (Protura: Acerentomidae: Nipponentominae). Annals of the Entomological Society of America 107(4): 728-733. https://doi.org/10.1603/AN13160

Szeptycki A (1988) New genera and species of Protura from the Altai Mts. Acta Zoologica Cracoviensa 31: 297-362.

Szeptycki A (2007) Catalogue of the world Protura. Acta Zoologica Cracoviensa 50B(1): 1-210. Yin WY (1980) Studies on Chinese Protura: Description of new species and new genera of the family Acerentomidae with discussions on their phylogenetic significance. Contributions from Shanghai Institute of Entomology 1980: 135-156. [In Chinese with English summary]

Yin WY (1983) Grouping the known genera of Protura under eight families with keys for determination. Contributions from Shanghai Institute of Entomology 3(1982-1983): 151-163. [In Chinese with English summary] 